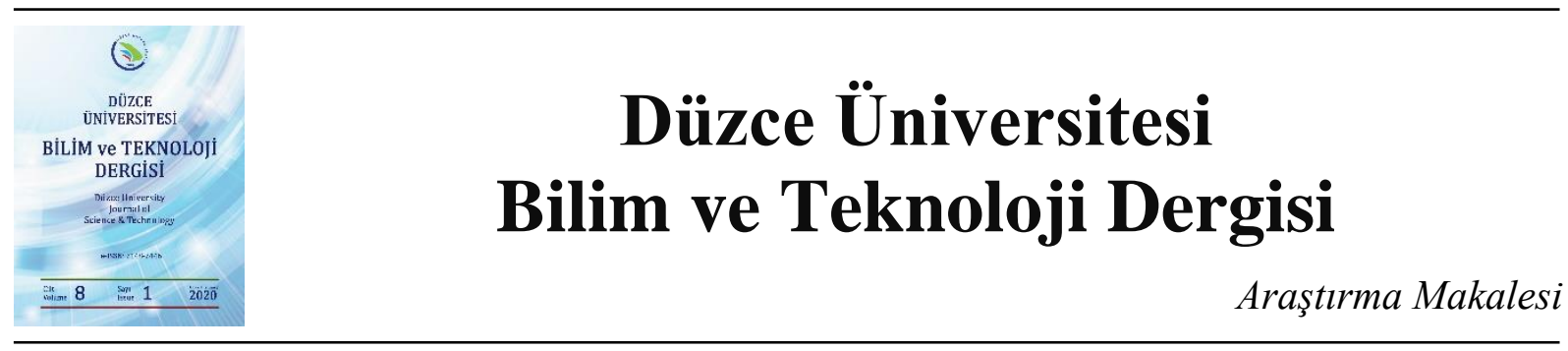

\section{Termokimyasal Yöntemle Bor ve Titanyum kaplı AISI D2 Kesici Takımlarının Kaplama Özelliklerinin ve Talaşlı İşlem Kabiliyetinin İncelenmesi}

\author{
Şenol ERTÜRK ${ }^{\text {a,*, }}$ (iD Fehmi ERZINCANLI ${ }^{\mathrm{a}}$ \\ ${ }^{a}$ Makine Mühendisliği Bölümü, Mühendislik Fakültesi, Düzce Üniversitesi, Düzce, TÜRKIYE \\ * Sorumlu yazarin e-posta adresi: senol14118@ogr.duzce.edu.tr
}

DOI: $10.29130 /$ dubited.519356

\begin{abstract}
ÖZET
Talaş kaldırma işlemlerinde kullanılan kesici takımların ömürleri aşınma nedeniyle sınırlıdır. Bu nedenle kesici takımların aşınma direncinin arttırılması ekonomik kayıpların en aza indirilmesi açısından büyük önem taşımaktadır. Uygulanan farklı kaplama yöntemleriyle, takımlar çok daha sert bileşiklerden oluşan malzemelerle kaplanıp aşınma direnci geliştirilebilmektedir. Kaplama sayesinde bir yandan takım sertliği artarken diğer taraftan tokluğu muhafaza edilebilmesi önemli bir avantajdır. Bu çalışmada AISI D2 çeliğinden üretilmiş kesici takımlar termo-reaktif difüzyon yöntemi ile 1 saat boyunca $950{ }^{\circ} \mathrm{C}$ ve $1050{ }^{\circ} \mathrm{C}$ de borla ve titanyumla kaplanmıştır. Kaplanan numuneler, SEM, x 1şını, EDS analizi ve mikrosertlik testi yapılarak karakterize edilmiştir. Numunelerin aşınma direncini ve tornada işlenmiş yüzey pürüzlülüğ̈̈nü gözlemlemek için talaş kaldırma testleri yapılmıştır. Talaş kaldırma deneyleri, DIN 1651 otomat çeliği üzerinde gerçekleştirilmiştir. Silindirik tornalama testlerinin uygulandığı çalışma da 38-73-138 m/dk ve 0,08, 0,12, 0,16 mm/dev olmak üzere üç farklı kesme hızı ve ilerleme değeri kullanılmıştır. Sonuçlar, borlama ve titanyumlama işlemleri uygulanan takımın sadece borlanan takıma göre $\% 50$ oranında daha iyi performans sergilediği göstermiștir. Yüzey pürüzlülüğü açısından genel olarak kaplanmış ve kaplanmamış takımlar arasında önemli bir fark olmadığı belirlenmiştir.
\end{abstract}

Anahtar Kelimeler: Termo-kimyasal kaplama, Borlama, Titanyumlama, Takım aşınması, Yüzey pürüzlülü̈̆̈̈

\section{Investigation of Coating Properties and Machining Capability of Boron and Titanium Coated AISI D2 Cutting Tools by Thermochemical Method}

\begin{abstract}
The life of cutting tools used in machining operations is limited due to wear. Therefore, increasing of wear resistance of cutting tools is very important for minimizing the economic losses. By applying different coating techniques, tool materials can be coated with much harder compounds in order to increase wear resistance. Thanks to the coating, it is an important advantage on the one hand while increasing tool hardness, on the other hand to retain toughness. In this study, cutting tools made of AISI D2 steel are coated with boron and titanium at $950{ }^{\circ} \mathrm{C}$ and $1050{ }^{\circ} \mathrm{C}$ for 1 hour by thermo reactive diffusion method. The coated samples were characterised by SEM, Xray diffraction, EDS analysis and micro hardness testing. Machining tests were carried out to observe wear resistance of the samples and machined surface roughness on a lathe. The machining tests were performed on DIN 1651 stees. Cylindrical turning tests are applied in the study, 38-73-138 $\mathrm{m} / \mathrm{min}$ and 0,08, 0,12, 0,16 $\mathrm{mm} / \mathrm{rev}$ three different cutting speeds and feed rate were used. The results showed that boronized and titanized samples exhibited approximately $50 \%$ better performance than the samples which is only boronized. Generally, in terms of surface roughness, no significant differences were observed among the results of coated and uncoated samples.
\end{abstract}

Keywords: Thermo-chemical coating, Boronizing, Titanizing, Tool wear, Surface roughness 


\section{GIRIS}

Mekanik parçaların maruz kaldığı aşınma ve korozyon, önemli ölçüde ekonomik kayıba sebep olmaktadır. Bu nedenle, zor şartlarda çalışan mekanik parçaların ekonomik ömürlerinin uzatılası maksadıyla dış yüzeylere uygulanabilen farklı kaplama tür ve yöntemleri geliştirilmiştir [1]. Yüzey işlemleri, sertlik, yorulma, aşınma, korozyon, 1sıl şok direnci gibi mekanik ve tribolojik özelliklerin bir veya birkaçını geliştirmek amacıyla uygulanmaktadır. Bu özellikler arasında parçanın aşınma ve korozyon direncinin arttırılması yaygınlık ve önem açısından ilk sıralarda yer almaktadır. Kesici takımlarda ve sürtünerek çalışan makine elemanlarında ortaya çıkan aşınma problemlerini azaltmak için birçok yüzey iyileştirme işlemi uygulanmaktadır [2].

Borlama yüksek sıcaklılarda difüzyona dayalı kimyasal reaksiyonla gerçekleşen bir yüzey sertleştirme işlemidir. Çelik esaslı malzemelere uygulandığında malzeme yüzeyinde sert borür tabakaları oluşur [3, 4]. Borlanan yüzeylerde genellikle yüksek aşınma ve düşük sürtünme direnciyle karakterize edilen $\mathrm{FeB} / \mathrm{Fe}_{2} \mathrm{~B} / \mathrm{TiB} / \mathrm{CrB} / \mathrm{Cr}_{2} \mathrm{~B}_{3}$ gibi bileşikler oluşturularak çok iyi abrasif ve adhesif aşınma direnci elde edilmektedir [5]. Buna ilaveten, borlanan yüzeyler seyreltilmiş asidik ve alkalik ortamlara karşı da yüksek korozyon/erozyon direnci sergileyebilmektedir [6]. Borlama işlemi sonrasında istenirse çeliklere 1sıl işlem de uygulanabilmektedir.

Günümüzde kesici takımların kaplanmasında fiziksel buhar biriktirme (PVD) ve kimyasal buhar biriktirme (CVD) yöntemleri seri üretimde büyük firmalarca yaygın olarak kullanılmaktadır. Fakat bu sistemlerin yüksek mali yatırım gerektirmesi bir dezavantaj teşkil etmektedir. Buna karşın, termo reaktif difüzyon (TRD) yöntemi nispeten basit ve ekonomik bir kaplama yöntemi olup çelikler üzerinde sert ve korozyon direnci yüksek kaplamaların elde edilmesine imkan vermektedir [7]. Titanyum, vanadyum, tantalyum, molibden gibi sert bileşik oluşturabilen metallere ait borür, nitrür, karbür, karbo-nitrür ve bor-nitrür bileşiklerinden meydana gelen kaplamalar uygulanabilmektedir. İşlem sonrasında elde edilen sert seramik katmanlar altlık malzemeyle reaksiyon sonucu meydana geldiğinden, metalürjik olarak birbirine bağlanmış yüksek mukavemetli altlık ve kaplama ara yüzeyi oluşur [8].

Birçok araştırmacı, farklı kaplamalar kullanarak etkilerini incelemişlerdir. Kolla Meheresh Gupta ve arkadaşları [9] üç tip PVD kaplı kesici takım (TiN, AlCrN ve TiAlN) geliştirmiş ve bu takımların kesme performansı C45 çeliğinin tornalamasında incelenmiştir. M. Staszuk ve arkadaşları [10] ALD+PVD hibrit kaplama malzemesi yapısının kaplama özellikleri üzerindeki etkisini belirlemişlerdir. Guangming Zheng ve arkadaşları [11] kesme parametrelerinin takım aşınma davranışı ve yüzey pürüzlülüğü üzerindeki etkisine odaklanmıştır. Kaplamalı karbür aracı ile kesme parametreleri deneysel incelenmiştir [12-14]. Çalışmada tek veya çok katmanlı kaplamalı kesici takımın aşınma mekanizması, yapışma, ufalanma, yorulma, difüzyon, oksidasyon parametreleri incelenmiştir. Çalışmada tek veya çok katmanlı kaplamalı kesici takımın aşınma mekanizması, yapışma, ufalanma, yorulma, difüzyon, oksidasyon parametreleri incelenmiştir.

Bu çalışmada AISI D2 çeliği, düşük maliyeti, kolay bulunabilirliği ve özelliklerinden dolayı Termokimyasal kaplamaya uygun bir çelik olduğu için bu çelikten üretilen kesici takımlar TRD yöntemiyle borlama ve titanyumlama işlemine tabi tutularak elde edilen kaplamanın karakterizasyonu yapılmıştır. Daha sonra, talaş kaldırma testleri uygulanarak, kaplanan ve kaplanamayan numunelerin aşınma davranışları deneysel olarak incelenmiştir.

\section{DENEYSEL CALISSMALAR}

\section{A. AISI D2 KESİCI TAKIM NUMUNELERI}

Deneylerde kullanılan kesici takım numuneleri, dairesel kesitli AISI D2 çeliğinden Şekil 1'de görülen geometri ve ölçülerde kesici takım olarak kullanabilecek şekilde üretilmiştir. Numuneler üzerinde 
homojen bir kaplama tabakası elde edebilmek için 1, 2 ve 3 nolu yüzeyler taşlandıktan sonra 1200 grit zımpara ile parlatılmıştır.
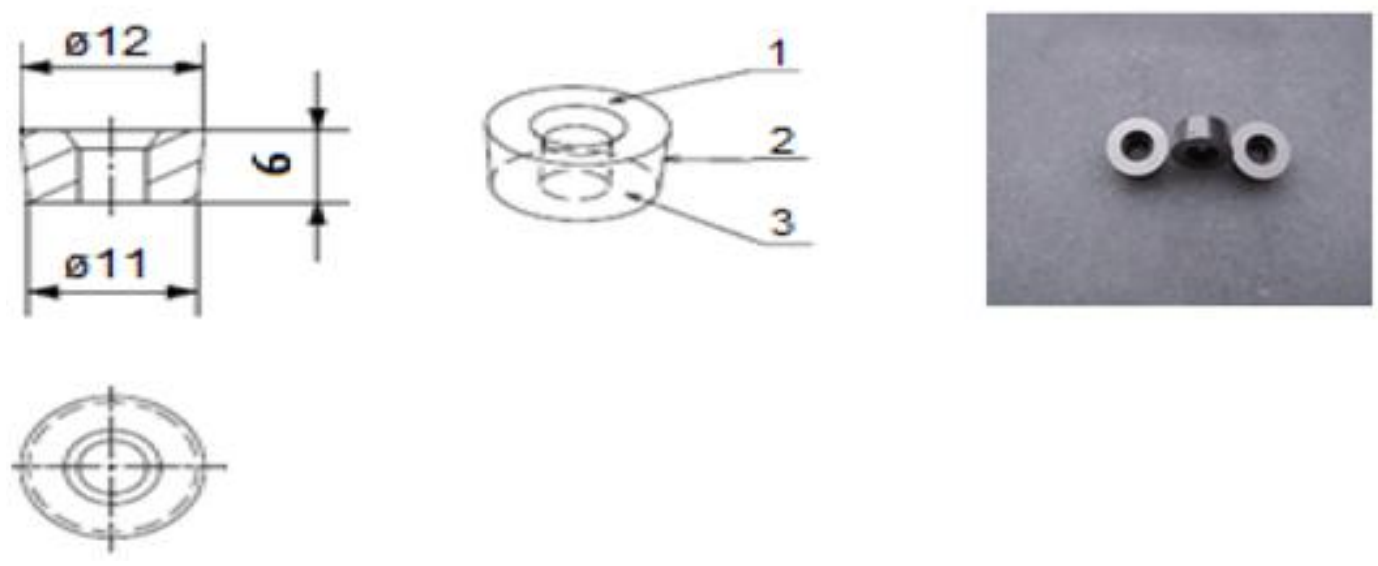

Şekil 1. AISI D2 kesici takım numunelerinin geometrik yapıları

D2 çeliğinin 1sıl ve mekanik özellikleri Tablo 1'de verilmiştir.

Tablo 1. D2 çeliğinin ısıl ve mekanik özellikleri

\begin{tabular}{ll}
\hline Özellik & Soğuk iş çeliği (D2) \\
\hline Sertleştirme $\left({ }^{\circ} \mathrm{C}\right)$ & $1190-1230$ \\
\hline Menevişleme $\left({ }^{\circ} \mathrm{C}\right)$ & $540-570$ \\
\hline Menevişlemeden sonra elde edilen yaklaşık sertlik (HRC) & $64-66$ \\
\hline Oda sıcaklığındaki yaklaşık yoğunluk & $8,1 \mathrm{~g} / \mathrm{cm}^{3}$ \\
\hline
\end{tabular}

Deneysel çalışmada kullanılan AISI D2 çeliğinin spektral analizi Tablo 2'de verilmiştir.

Tablo 2. AISI D2 takım çeliğinin spektral analizi

\begin{tabular}{cccccccccccc} 
Çeliğin Cinsi Kimyasal Bileşim (\% Ă̆ırlıkça) \\
\cline { 2 - 21 } & $\mathrm{C}$ & $\mathrm{Si}$ & $\mathrm{Mn}$ & $\mathrm{P}$ & $\mathrm{S}$ & $\mathrm{Cr}$ & $\mathrm{Ni}$ & $\mathrm{Mo}$ & $\mathrm{W}$ & $\mathrm{V}$ & $\mathrm{Fe}$ \\
\hline AISI D2 & 1,756 & 0,271 & 0,291 & 0,0353 & 0,0107 & 11,560 & 0,214 & 0,609 & 0,0150 & 1,00 & 84,106 \\
\hline
\end{tabular}

\section{B. TERMOKIMYYASAL YÖNTEMLE BORLAMA İSLEMI}

Borlama işlemi $1200{ }^{\circ} \mathrm{C}$ sıcaklığa çıkabilen $\pm 1{ }^{\circ} \mathrm{C}$ işlem hassasiyetine sahip elektrikli fırında gerçekleştirilmiştir. İşlemlerde $3 \mathrm{~mm}$ kalınlı̆̆ında AISI 316L paslanmaz çelikten yapılmış ø70x100 mm ölçülerinde ağzı kapatılabilen silindirik potalar kullanılmıştır. Borlama katı ortamda gerçekleştirilmiştir. Bor kaynağı olarak Ekabor-2 ve deoksidan olarak Ekrit tozu karışımları kullanılmıştır. Ekabor borlama ürünlerinin özellikleri Tablo 3'de verilmiştir. 
Tablo 3. Ekabor borlama ürünlerinin özellikleri [15]

\begin{tabular}{cccl}
\hline Tip & $\begin{array}{c}\text { Tane } \\
\text { Boyutu } \\
(\mu)\end{array}$ & $\begin{array}{c}\text { Yoğunluk } \\
\text { Kompakt } \\
\left(\mathrm{gr} / \mathrm{cm}^{3)}\right.\end{array}$ & \multicolumn{1}{c}{ Özellik } \\
\hline $\begin{array}{c}\text { EKabor } \\
1\end{array}$ & $\leq 150$ & 1,80 & $\begin{array}{l}\text { Yüzey kalitesi en yüksek tabaka için; parça yüzeyine } \\
\text { yapışmaya eğilimli }\end{array}$ \\
\hline $\begin{array}{c}\text { EKabor } \\
2\end{array}$ & $\leq 850$ & 1,50 & $\begin{array}{l}\text { Mükemmel yüzey kalitesi: işlem sonrası parçadan } \\
\text { kolaylıkla ayrılma }\end{array}$ \\
\hline $\begin{array}{c}\text { EKabor } \\
3\end{array}$ & $\leq 1,400$ & 0,95 & $\begin{array}{l}\text { Çok iyi yüzey kalitesi: işlem sonrasında toz akıcılığı hala } \\
\text { iyidir }\end{array}$ \\
\hline $\begin{array}{c}\text { EKabor } \\
\text { HM }\end{array}$ & $\leq 150$ & $0,95-1,50$ & $\begin{array}{l}\text { Çok iyi yüzey kalitesi: sert metal, küçük delik ve kalın } \\
\text { tabakalar için }\end{array}$ \\
\hline $\begin{array}{c}\text { EKabor } \\
\text { WB }\end{array}$ & $220-350$ & 0,95 & \begin{tabular}{l} 
Oksijensiz gaz atmosferde, akışkan yatakta borlama için \\
\hline $\begin{array}{c}\text { EKabor } \\
\text { Pasta }\end{array}$
\end{tabular}$-\begin{array}{l}\text { Daldırma, firça ile sürme ve püskürtme ile uygulanabilir, } \\
\text { inert gaz altında çalış1lmalı }\end{array}$ \\
\hline EKrit & $\leq 420$ & 1,55 & $\begin{array}{l}\text { Örtü malzemesi, borlama süresince toz borlama } \\
\text { ürünlerine oksijen sizmasını önler }\end{array}$ \\
\hline
\end{tabular}

Borlama işlemi $950^{\circ} \mathrm{C}$ sıcaklıkta 1 saat süre ile gerçekleştirilmiştir. Şekil 1'de ki ebatlarda hazırlanan kesici takım numuneleri şekil 2' deki gibi hazırlanan borlama tozu ile doldurulmuş olan potanın içerisine gömülmüş ve potanın kapağı sıkıca kapatılmıştır. Her bir borlama işlemi için yeni toz karışımları kullanılmıştır. Pota içerisine de, numune aralarında ve numune ile pota kenarı arasında en az $12 \mathrm{~mm}$ borlama tozu olacak şekilde yerleştirme yapılmış ve işlem sıcaklığına çıkartılmış olan elektrikli firınına yerleştirilmiştir. Borlama sonrası numuneler oda sıcaklığına kadar pota içerisinde soğutulmuşlardır.

\begin{tabular}{|c|}
\hline Kapak \\
\hline Şamot \\
\hline Ekrit $=\% 25$ \\
\hline Ekabor $2=\% 35$ \\
\hline NUMUNELER \\
\hline Ekabor $2=\% 25$ \\
\hline Ekrit $=\% 15$ \\
\hline
\end{tabular}

Şekil 2. Borlama potasının hazırlanması

\section{TERMOKIMYASAL YÖNTEMLE TİTANYUMLAMA İSLEMİ}

Titanyumlama işleminde kullanılan kimyasal tozların karışımı ağırlıkca \%50 ferro-titanyum, \%25 alumina (ticari saflıkta), \%15 Amonyum klorür $\left(\mathrm{NH}_{4} \mathrm{Cl}\right)$ ve $\% 10$ naftalin $\left(\mathrm{C}_{10} \mathrm{H}_{8}\right)$ den oluşmaktadır. Ferro titanyum analizi Tablo 4' de verilmiştir.

Tablo 4. Ferro-titanyumun kimyasal bileşimi

\begin{tabular}{cccccccccc}
\hline Malzeme & $\mathbf{T i}$ & $\mathbf{A l}$ & $\mathbf{S i}$ & $\mathbf{P}$ & $\mathbf{S}$ & $\mathbf{N}$ & $\mathbf{C}$ & $\mathbf{M n}$ & Size \\
\hline $\begin{array}{c}\text { Ferro } \\
\text { Titanyum }\end{array}$ & 72,80 & 4,69 & 0,18 & 0,006 & 0,006 & 0,19 & 0,20 & 1,50 & $10-50 \mathrm{~mm}$ \\
\hline
\end{tabular}

Kaplama potasının tabanına alumina, hemen üstüne kaplama tozu, numune, kaplama tozu, alumina ve çok az naftalin ilavesi ile kapak kapatılmakta ve şamot çamuru ile sızdırmazlık sağlanmıştır (Şekil 3). İşlem sıcaklığına çıkarılan firına daha önce hazırlanmış olan potalar yerleştirilmiştir. Her deney için toz 
karışımı yeniden hazırlanmıştır. Termokimyasal titanyumlama işlemi $1050^{\circ} \mathrm{C}$ sıcaklıkta 1 saat süreyle gerçekleştirilmiştir. Kaplama işlemi sonrasında numuneler açık atmosferde oda sıcaklığına kadar soğutulmuştur.

\begin{tabular}{|c|}
\hline Kapak \\
\hline Şamot \\
\hline $\mathrm{Al}_{2} \mathrm{O}_{3}$ \\
\hline $\begin{array}{c}\text { Numuneler } \\
\text { Karışım }\end{array}$ \\
\hline $\mathrm{Al}_{2} \mathrm{O}_{3}$ \\
\hline
\end{tabular}

Şekil 3. Titanyumlama potasınin hazırlanması

\section{MİKROYAPI İNCELEMELERİ}

Termo-kimyasal yöntemle borlama ve titanyumlama işlemine tabi tutulan kesici takım numuneleri kesilip bakalite alma işleminden sonra metalografik numune hazırlama teknikleri ile 400-600-8001000-1200 zımparalarla zımparalama işlemine tabi tutulmuştur. 1200 zımpara ile zımparalama işleminden sonra $0,3 \mu \mathrm{m}$ 'luk alumina solüsyonla parlatma işlemi yapılmıştır. Daha sonra numuneler \%3'lük Nital ile dağlanarak mikroyapılar ortaya çıkarılmıştır. Metalografik olarak hazırlanan numuneler optik mikroskop ile incelenmiştir.

Kaplama tabakasında oluşan fazların ve özelliklerinin belirlenmesinde X- 1şını difraksiyon (XRD) analizi kullanılmıştır. Kaplama tabakasındaki elementlerin dağılımını ve morfolojisini incelemek amacıyla taramalı elektron mikroskobu (SEM) ve elementler analizi spektrometresi (EDS) yapılmıştır. Her malzemenin farklı borlama ve titanyumlama sıcaklığı ve süresi için mikroyapı görüntüleri elde edilmiştir.

Kaplama tabakalarının ve matrisin sertlik ölçümleri mikrosertlik cihazında $50 \mathrm{~g}$ yük altında knoop sertlik ucu kullanılarak gerçekleştirilmiştir. Ölçme işlemleri kaplama tabakasının dış yüzeyinden gerçekleştirilmiştir.

\section{E. TALAŞ KALDIRMA DENEYI}

Kaplanan numunelerle çap1 $50 \mathrm{~mm}$ olan otomat çeliği üzerinde talaş kaldırma deneyi gerçekleştirilmiştir. Deneyde iş parçası olarak kullanılan DIN 1651 otomat çeliğinin kimyasal bileşimi Tablo 5'de verilmiştir. Talaş kaldırma işlemi, 0,25 mm sabit talaş derinliği kullanılarak her bir deney için iş parçası üzerinde $200 \mathrm{~mm}$ boyunda bir mesafe işlenerek gerçekleştirilmiştir. Bu mesafenin ilk 40 $\mathrm{mm}$ ve son 40 mm'lik kısımları üzerinde yüzey pürüzlülük ölçümleri gerçekleştirilmiştir. Böylece takım aşınmasının yüzey pürüzlülüğüne etkisini belirlemek mümkün olmuştur. İşlem sonunda kesici takım serbest yüzeyinde meydana gelen takım aşınması optik mikroskopta ölçülmüştür. Deneyler $7 \mathrm{~kW}$ gücünde üniversal torna tezgahında $38,73,138 \mathrm{~m} / \mathrm{dk}$ kesme hızlarında ve $0,08,0,12,0,16 \mathrm{~mm} / \mathrm{dev}$ ilerleme şartlarında gerçekleştirilmiştir. Deneylerde soğutma sıvısı kullanılmamıştır.

Tablo 5. Deneysel çalışmada kullanılan DIN 1651 otomat çeliğinin kimyasal bileşimi

\begin{tabular}{ccccccccc}
\hline Malzeme & Fe & $\mathbf{C}$ & $\mathbf{S i}$ & $\mathbf{M n}$ & $\mathbf{P}$ & $\mathbf{S}$ & $\mathbf{C r}$ & Mo \\
\hline & 97,9 & 0,042 & $<0,05$ & 1,193 & 0,062 & $>0,170$ & 0,094 & 0,010 \\
\cline { 2 - 10 } OTOMAT & $\mathrm{Ni}$ & $\mathrm{Al}$ & $\mathrm{Co}$ & $\mathrm{Cu}$ & $\mathrm{Nb}$ & $\mathrm{Ti}$ & $\mathrm{V}$ & $\mathrm{W}$ \\
\cline { 2 - 10 } ÇELİĞI & 0,074 & 0,001 & 0,0096 & 0,0762 & $<0.0020$ & $<0,0020$ & $<0,0020$ & $<0,0100$ \\
\cline { 2 - 9 } (DIN 1651) & $\mathrm{Pb}$ & $\mathrm{Sn}$ & $\mathrm{B}$ & $\mathrm{Ca}$ & $\mathrm{Zr}$ & $\mathrm{As}$ & & \\
& 0,295 & 0,0137 & 0,0105 & 0,0001 & 0,0023 & 0,0142 & & \\
& & & & & & & & \\
\hline
\end{tabular}


Kesici takım şeklinde hazırlanan kaplamasız, borlanmış ve titanyum kaplı üç farklı kesici takım numuneleri ile otomat çeliğinin tornalanması sonucunda kesme hızı- yüzey pürüzlülüğü ve ilerleme hızı yüzey pürüzlülüğü etkileri incelenmiştir.

Her bir deney için $200 \mathrm{~mm}$ boyundaki iş parçası üzerinde ilk $40 \mathrm{~mm}$ ve son $40 \mathrm{~mm}$ 'lik kısımları üzerinde yüzey pürüzlülük ölçümleri gerçekleştirilmiştir. Böylece takım aşınmasının yüzey pürüzlülüğüne etkisini belirlemek mümkün olmuştur.

\section{DENEY SONUCLARI}

\section{A. BORLANAN KESİCI TAKIMIN MİKROYAPI ÖZELLİKLERİ}

Metalografi teknikleri ile hazırlanan borlanmış AISI D2 kesici takım numunelerinin optik mikroskop incelemeleri neticesinde, kaplama işlemine tabi tutulan bütün kesici takımlarda kaplama tabakası açık bir şekilde görülmektedir. Yüzeyde bir tabaka halinde kaplamanın gerçekleştiği, kaplamanın matristen farklı bir renk arzetmesi nedeniyle ayırt edilmiştir. İncelemelerde kaplanan yüzeylerde düz, homojen ve süreklilik arzeden bir tabakanın oluştuğu görülmüștür. Numuneler üzerinde yapılan optik mikroskop incelemeleri sonucunda, kaplama işlemine tabi tutulan bütün numunelerde kaplama tabakası, kaplamamatris arayüzeyi ve matris açık bir şekilde görülmüş̧ür. Oluşan borür tabakasının kalınlığının borlama süresi ve sıcaklığına, çeliklerin bileşiminde bulunan alaşım elementlerine bağlı olarak değiştiği görülmüştür. Sırasıyla borlannmış bölge, geçiş bölgesi ve altlıktan oluşmaktadır. Çalışmada elde edilen mikroyapı görüntülerinin literatürde yer alan benzer çalışmalarla uyum içinde olduğu görülmektedir. Yapılan çalışmada AISI D2 numuneler üzerinde $950{ }^{\circ} \mathrm{C}$ sıcaklık ve 1 saat sürede gerçekleştirilen borlama işlemi sonucunda, yüzey bölgesinde 15-25 $\mu \mathrm{m}$ kalınlığında borür tabakasının oluştuğu SEM incelemeleri sonucunda tespit edilmiştir (Şekil 4).

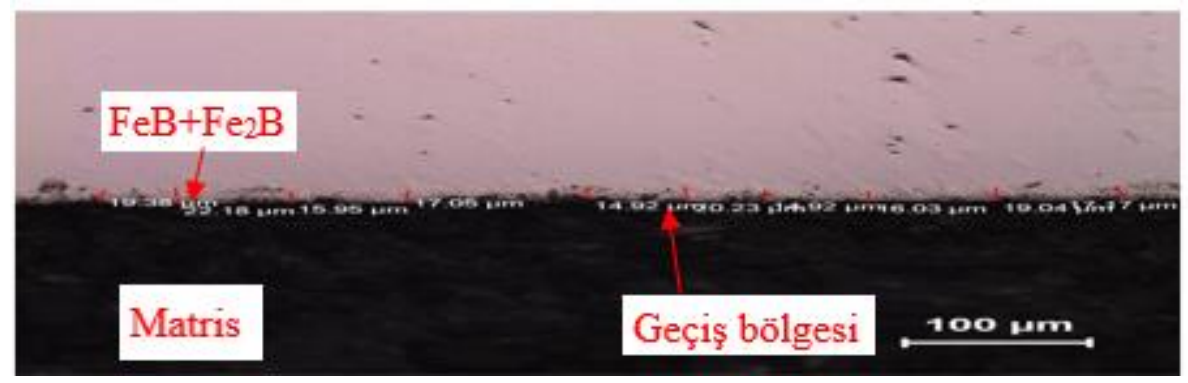

Şekil 4. $950^{\circ} \mathrm{C}$ sicaklıkta 1 saat borlanan AISI D2 çeliğinin mikroyapısı

\section{B. TITTANYUMLANAN KESICİ TAKIMIN MIKKROYAPI ÖZELLIKKLERİ}

D2 kesici takım numunelerinin borlanmasından sonra aynı numuneler $1050{ }^{\circ} \mathrm{C}$ ' de 1 saat süre ile titanyum ile reaksiyona sokulmuşlardır. İşlem sonucunda D2 numunelerinde x 1şınında yapılan incelemede 1-2 $\mu \mathrm{m}$ titanyumlanmış tabakanın meydana geldiği görülmüş̧ür (Şekil 5). 


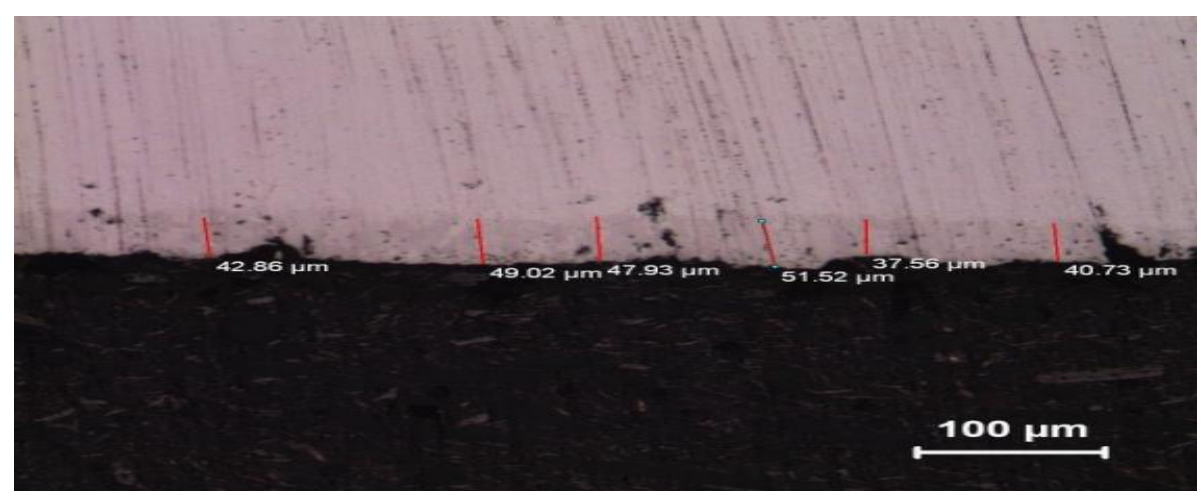

Şekil 5. $950^{\circ} \mathrm{C}$ slcaklıkta 1 saat borlanan ve ardından $1050^{\circ} \mathrm{C}$ ' de 1 saat titanyumlanan AISI D2 çeliğinin mikroyapıs

\section{X IŞINI DIFRAKSIYYON ANALIZİ}

Kaplama tabakasında oluşan fazları tespit edebilmek için $\mathrm{x}$ - 1şınları difraksiyon analiz yöntemi kullanılmıştır. D2 numunelerinin X ışını analizi Şekil 6 ve Şekil 7' de sırası ile verilmiştir. X ışını analiz sonucunda, borlanan çeliklerin yüzeylerinde $\mathrm{FeB}$ ve $\mathrm{F}_{2} \mathrm{~B}$ borürleri oluşmuştur (Şekil 6), Borlama işleminden sonra titanyumlanan $\mathrm{D} 2$ çeliklerinde $\mathrm{TiN}, \mathrm{TiC}, \mathrm{TiB}_{2}$ bileşiklerinin varlı̆̆ $\mathrm{X}$ 1şını incelemeleri ile tespit edilmiştir (Şekil 7).

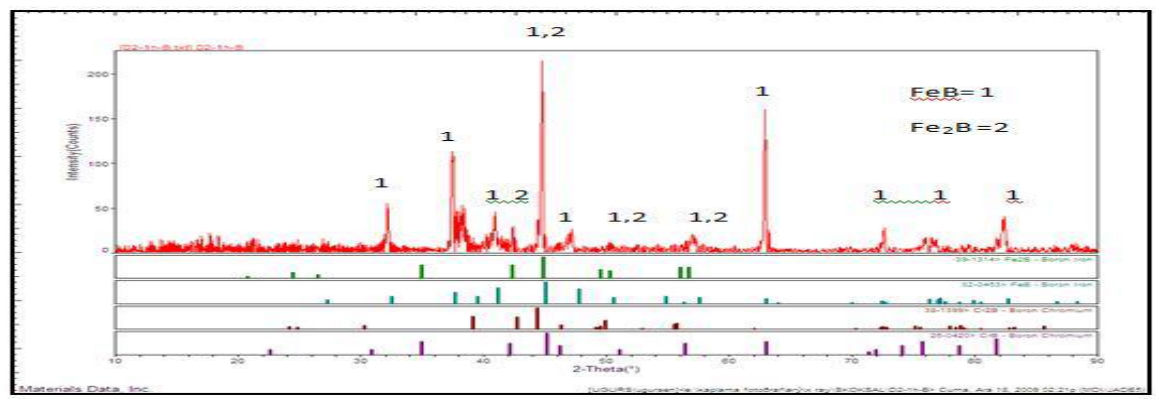

Şekil 6. $950^{\circ}$ C sıcaklıkta 1 saat borlanan AISI D2 çeliğinin x- ışııı analizi

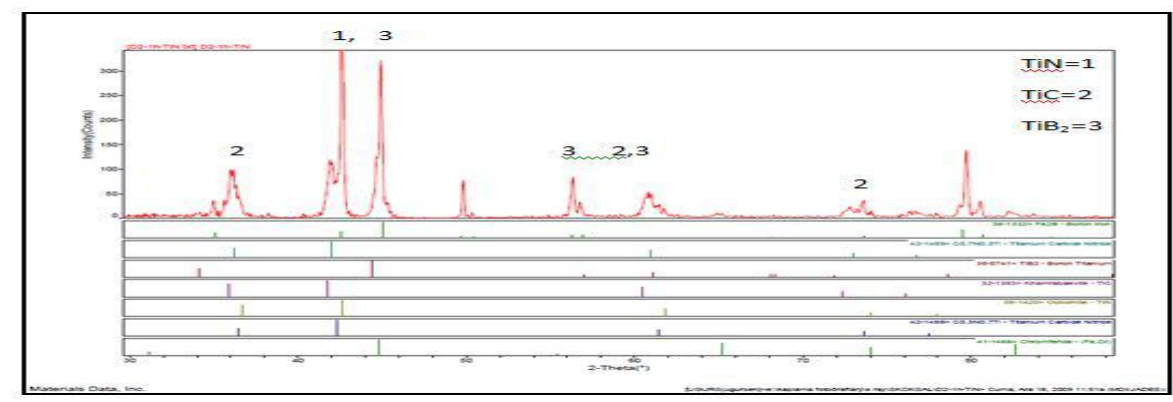

Şekil 7. $950^{\circ} \mathrm{C}$ sıcaklıkta 1 saat borlanan ve ardından $1050^{\circ} \mathrm{C}$ 'de 1 saat titanyumlana AISI D2 çeliğinin $x$ - ışını analizi

\section{TARAMALI ELEKTRON MIKROSKOBU (SEM) İNCELEMESI}

Taramalı elektron mikroskobu ile kaplanmış D2 çeliklerinin yüzeyinde oluşan kaplama tabakasının yapısı ve elementlerin tabaka içerisinde lineer dağılımları incelenerek bazı bölgelerin noktasal analizleri gerçekleştirilmiştir. Genel olarak kaplama tabakasının dış yüzeyinin koyu renkli olarak görülen $\mathrm{FeB}$ fazından, iç kısımlarda daha açık renkli $\mathrm{Fe}_{2} \mathrm{~B}$ fazından meydana geldiği görülmektedir (Şekil 8, 9). 


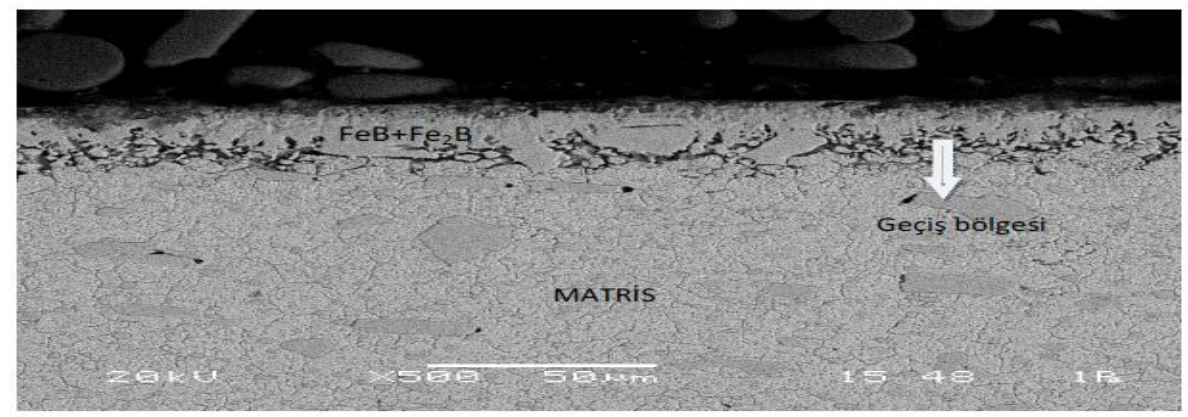

Şekil 8. $950^{\circ}$ C sıcakllkta 1 saat borlanan AISI D2 çeliğinin SEM-BEI görüntüsü

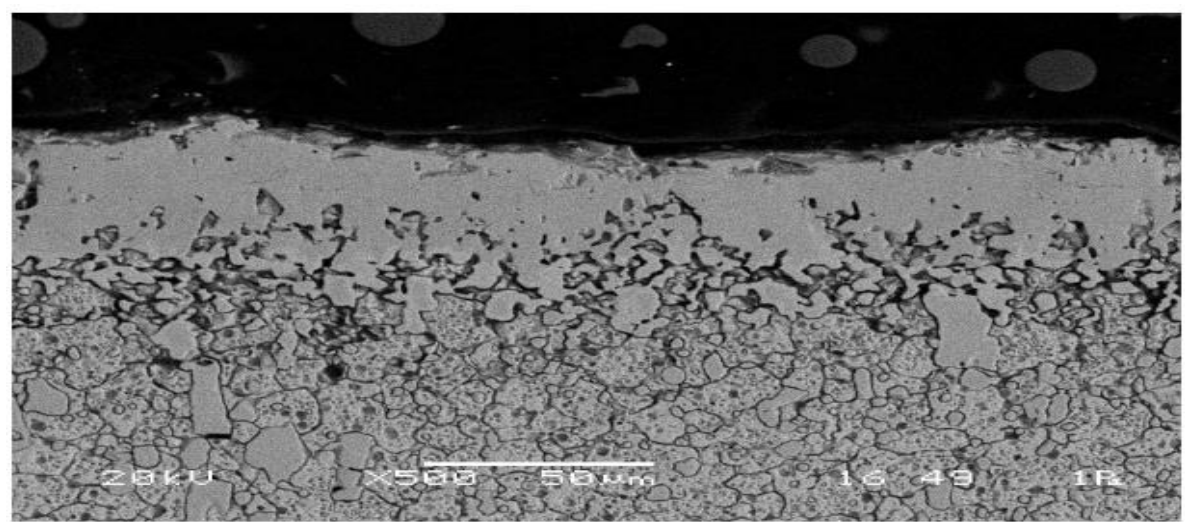

Şekil 9. $950^{\circ} \mathrm{C}$ sicaklikta 1 saat borlanan ve ardından $1050^{\circ} \mathrm{C} 2$ de 1 saat titanyumlanan AISI D2 çeliğinin SEM-BEI görüntüsü

Borlanan ve ardından titanyumlanan D2 çeliklerinin bazı bölgelerinden noktasal analizleri alınarak kaplama tabakası içerisinde bulunan elementler incelenmiştir (Şekil 10-18). Yapılan incelemelerde numunelerin yüzeylerinde titanyum oranlarının düşük olduğu görülmüştür. Bunun nedeni kaplamadaki titanyum oranından, kaplama sıcaklığından ve kaplama süresinden kaynaklandığı düşünülmektedir. Oluşan borür tabakasının kalınlığının da borlama süresi ve sıcaklığına, çeliklerin bileşiminde bulunan alaşım elementlerine bağlı olarak değiştiği görülmüş̧ür.

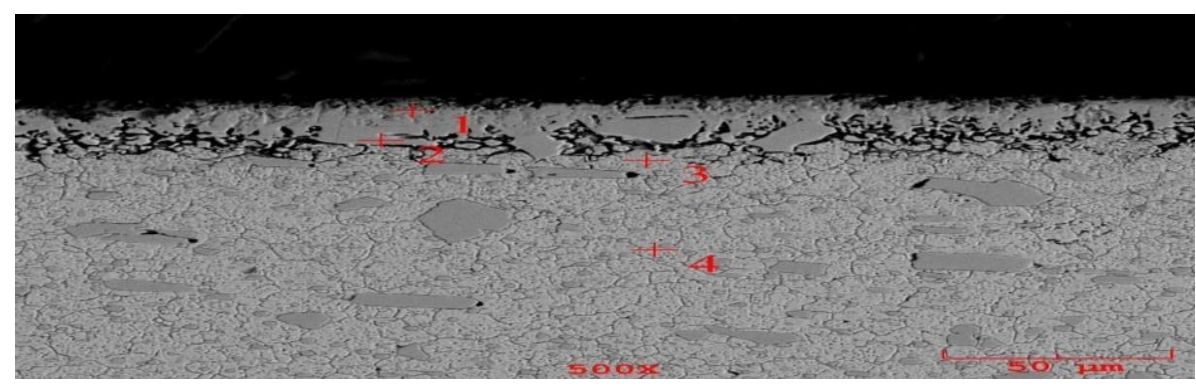

Şekil 10. $950^{\circ} \mathrm{C}$ sıcaklikta 1 saat borlanan AISI D2 çelik numunenin SEM mikroyapı görüntüsü üzerinde lineer analiz alınan bölgeler 


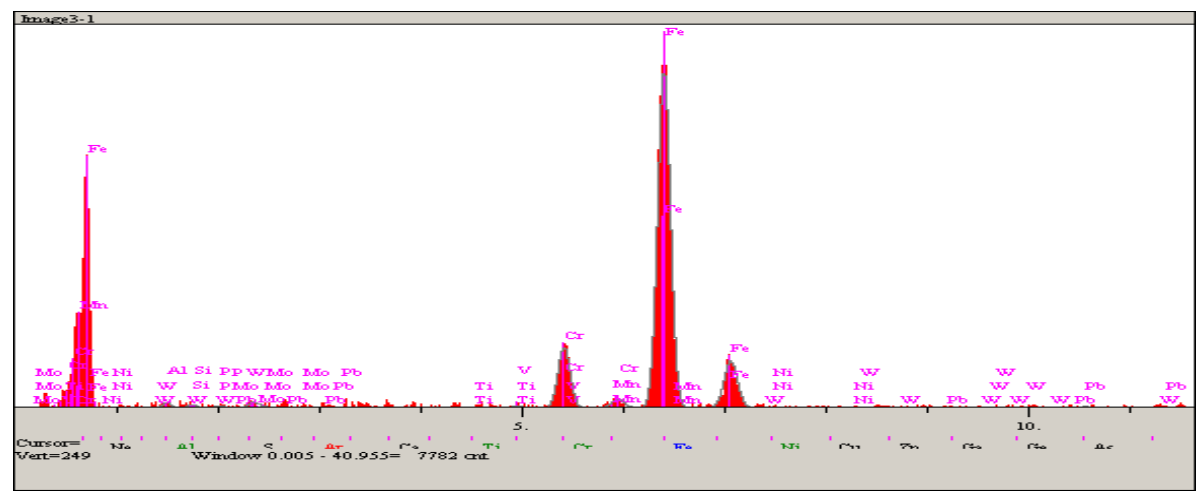

Şekil 11. $950^{\circ} \mathrm{C}$ sıcaklıta 1 saat borlanan AISI D2 çelik numunenin SEM mikroyapı görüntüsü üzerinden alınan 1. Noktanın noktasal analiz diyagramı

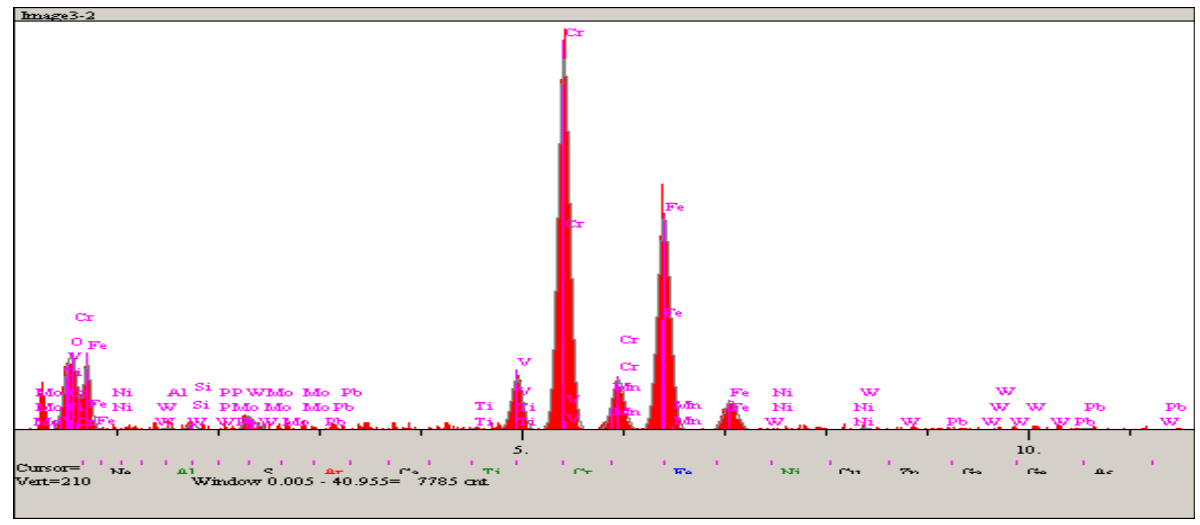

Şekil 12. $950^{\circ} \mathrm{C}$ sıcaklıkta 1 saat borlanan AISI D2 çelik numunenin SEM mikroyapı görüntüsü üzerinden alınan 2. Noktanın noktasal analiz diyagramı

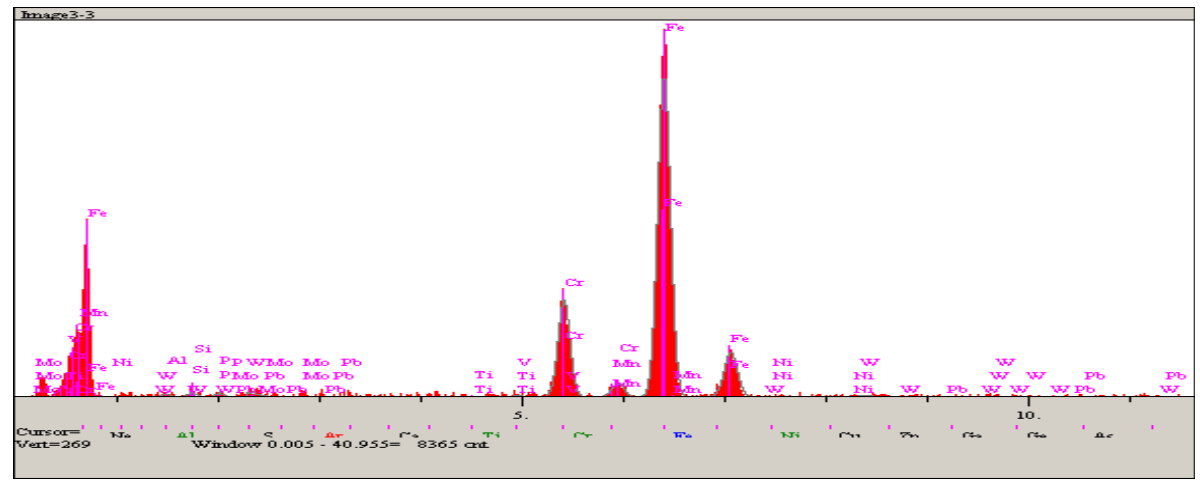

Şekil 13. $950^{\circ} \mathrm{C}$ slcaklıkta 1 saat borlanan AISI D2 çelik numunenin SEM mikroyapı görüntüsü üzerinden alınan 3. Noktanın noktasal analiz diyagramı 


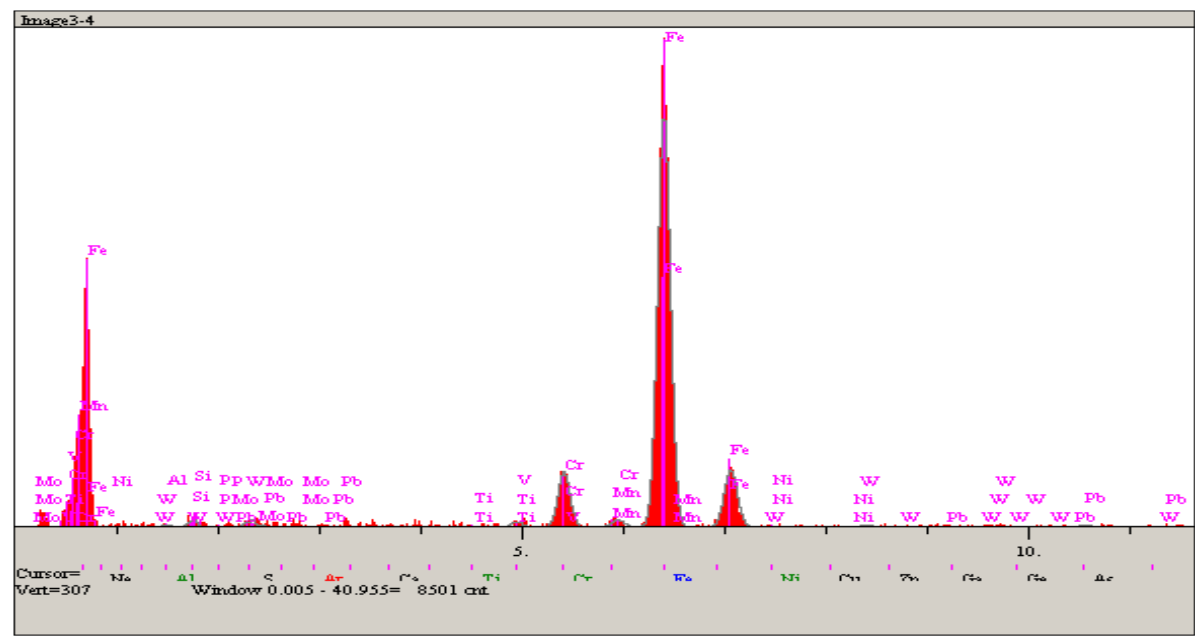

Şekil 14. $950^{\circ} \mathrm{C}$ sıcaklikta 1 saat borlanan AISI D2 çelik numunenin SEM mikroyapı görüntüsü üzerinden alınan 4. Noktanin noktasal analiz diyagramı

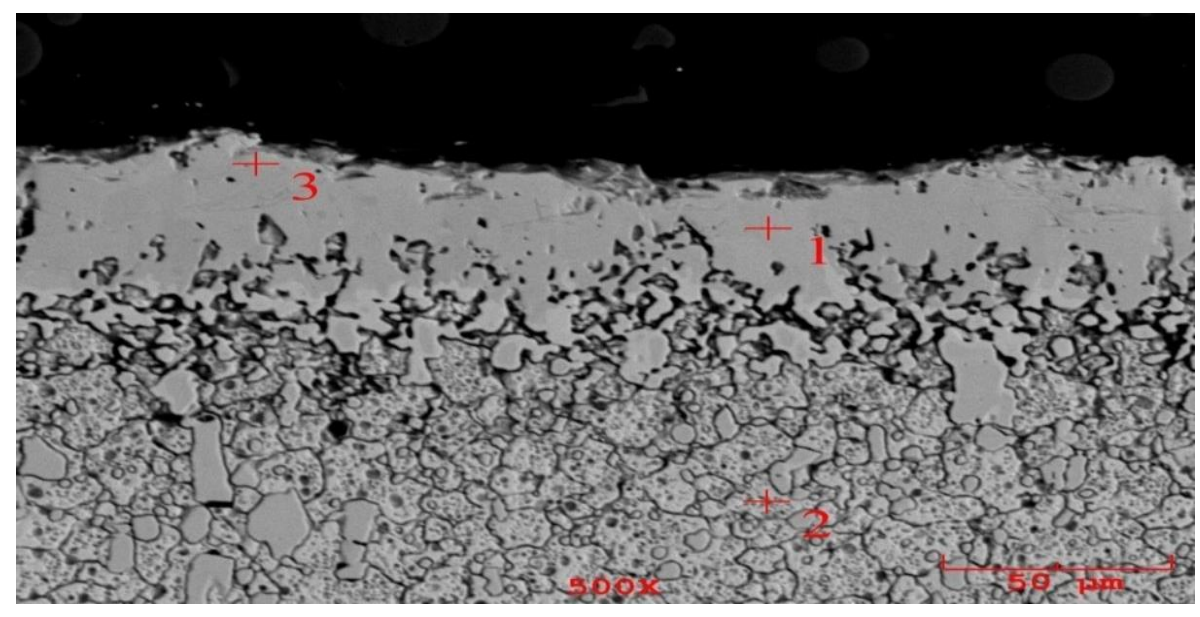

Şekil 15. $950^{\circ} \mathrm{C}$ sicaklikta 1 saat borlanan ve ardindan $1050^{\circ} \mathrm{C}$ ' de 1 saat titanyumlanan AISI D2 çelik numunenin SEM mikroyapı görüntüsü üzerinde lineer analiz alınan bölgeler

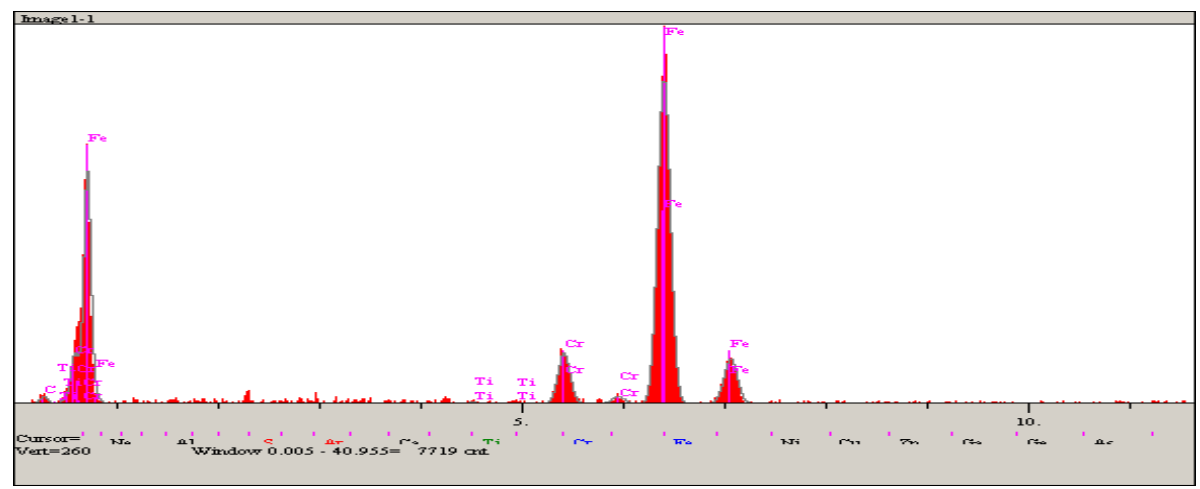

Şekil 16. $950^{\circ} \mathrm{C}$ sicaklikta 1 saat borlanan, ardindan $1050^{\circ} \mathrm{C}$ ' de 1 saat titanyumlanan AISI D2 çelik numunenin SEM mikroyapı görüntüsü üzerinden alınan 1. Noktanın noktasal analiz diyagramı 


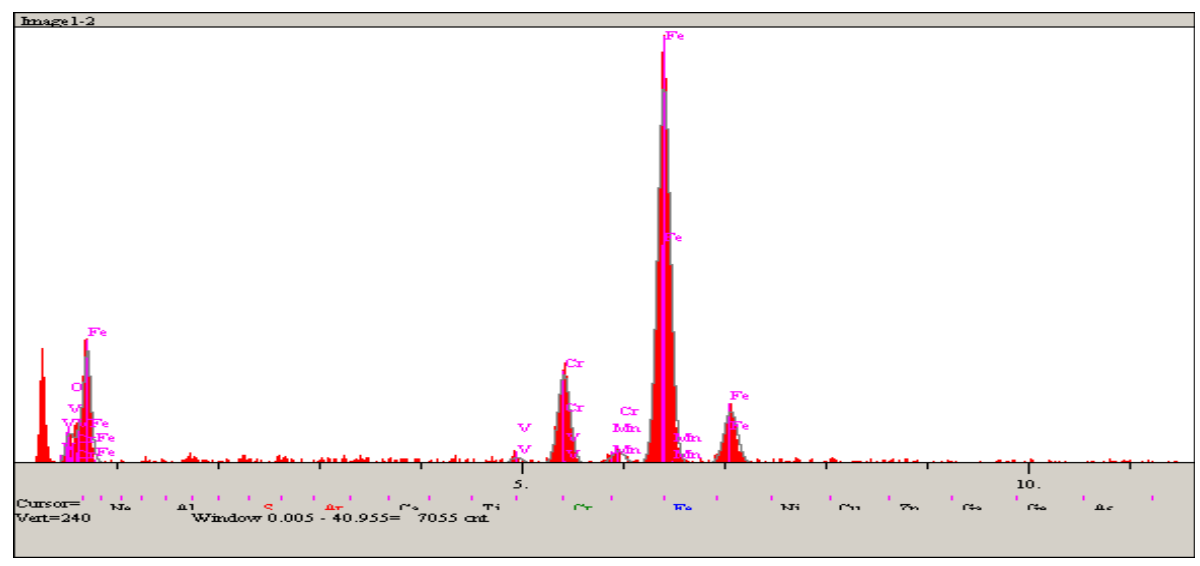

Şekil 17. $950^{\circ} \mathrm{C}$ sicaklıkta 1 saat borlanan, ardından $1050^{\circ} \mathrm{C}$ ' de 1 saat titanyumlanan AISI D2 çelik numunenin SEM mikroyapı görüntüsü üzerinden alınan 2. Noktanın noktasal analiz diyagramı

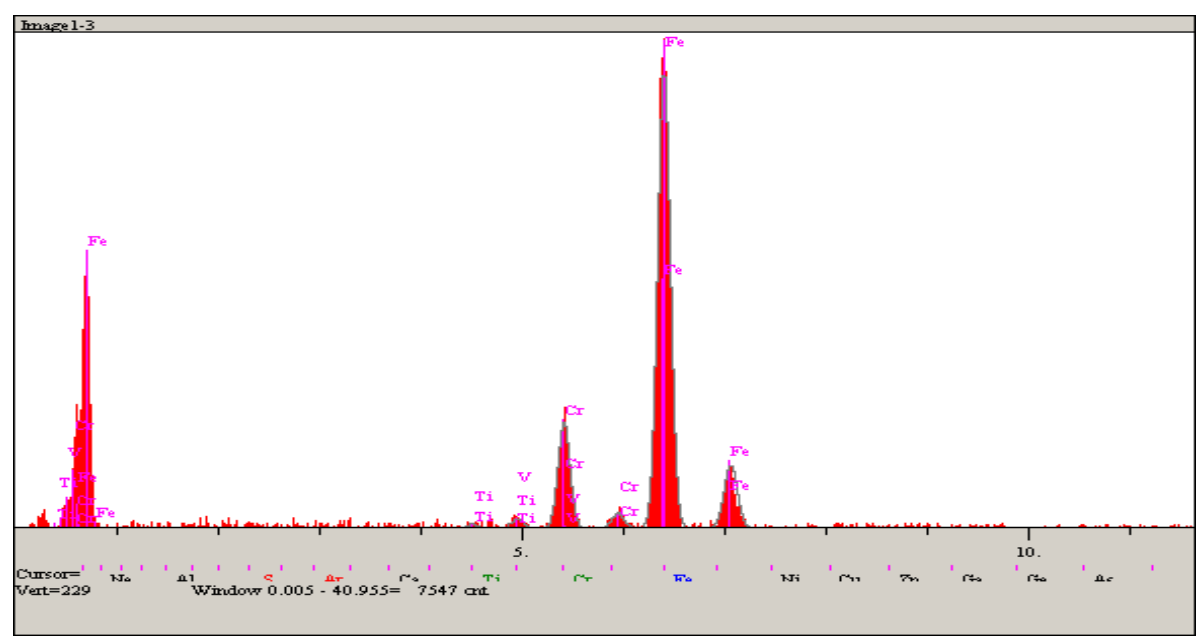

Şekil 18. $950^{\circ} \mathrm{C}$ sicaklıkta 1 saat borlanan, ardından $1050^{\circ} \mathrm{C}$ ' de 1 saat titanyumlanan AISI D2 çelik numunenin SEM mikroyapı görüntüsü üzerinden alınan 3. Noktanın noktasal analiz diyagramı

\section{E. SERTLIK ÖLÇÜMÜ}

Sertlik ölçümleri borlanan ve titanyumlanan numunelerin yüzey sertliği, kırılma tokluğu ve aşınma gibi mekanik özelliklerine etkisinin ortaya çıkarılması açısından önemlidir. Sertlik ölçümleri kaplanan numunelerin yüzeyine dik doğrultuda ilerleyerek gerçekleştirilmiş̧ir. Ölçüm sonuçları Tablo 6' da verilmiştir. Kaplama yüzeyine dik yapılan sertlik ölçümlerinde borlanan kesici takımların sertliğinin $2000 \mathrm{HV}$, borlanan ve ardından titanyumlanan D2 kesici takımlarının sertliğinin ise $2800 \mathrm{HV}$ olduğu belirlenmiştir. Tablo incelendiğinde en yüksek sertliğe sahip numunelerin titanyum ile kaplanan, sonra borlanan, daha sonra da 1sıl işlem uygulanan numuneler şeklinde sıralandığı görülmektedir.

Tablo 6. Sertlik ölçüm değerleri

\begin{tabular}{ccccc}
\hline \multirow{2}{*}{$\begin{array}{c}\text { Çeliğin } \\
\text { adı }\end{array}$} & Kaplama adı & $\begin{array}{c}\text { Uygulanan } \\
\text { yük (gr) }\end{array}$ & $\begin{array}{c}\text { Ölçülen } \\
\text { sertliği } \\
\text { (yaklaşı) }\end{array}$ & $\begin{array}{c}\text { HV } \\
\text { sertliŏi } \\
\text { (yaklaşı) }\end{array}$ \\
\hline \multirow{3}{*}{ D2 } & Bor & 50 & $1442 \mathrm{HK}$ & $2000 \mathrm{HV}$ \\
\cline { 2 - 5 } & Borlama+titanyumlama & 50 & $2517 \mathrm{HK}$ & $2800 \mathrm{HV}$ \\
\cline { 2 - 5 } & Is1l işlem & & $60 \mathrm{HRC}$ & $690 \mathrm{HV}$ \\
\cline { 2 - 5 } & İşlem görmemiş & 100 & $335 \mathrm{HK}$ & $350 \mathrm{HV}$ \\
\hline
\end{tabular}




\section{F. TAKIM TÜRLERININ VE ISŞLEM PARAMETRELERININ YÜZEY PÜRÜZLÜLÜĞÜNE ETKİSi}

Kesici takım olarak üretilen kaplanmış ve kaplanmamış D2 numunelerle otomat çeliği üzerinde talaş kaldırma testi yapılarak yüzey pürüzlülüğü ve takım aşınması incelenmiştir. Sonuçlar Şekil 19'da gösterilmiştir.

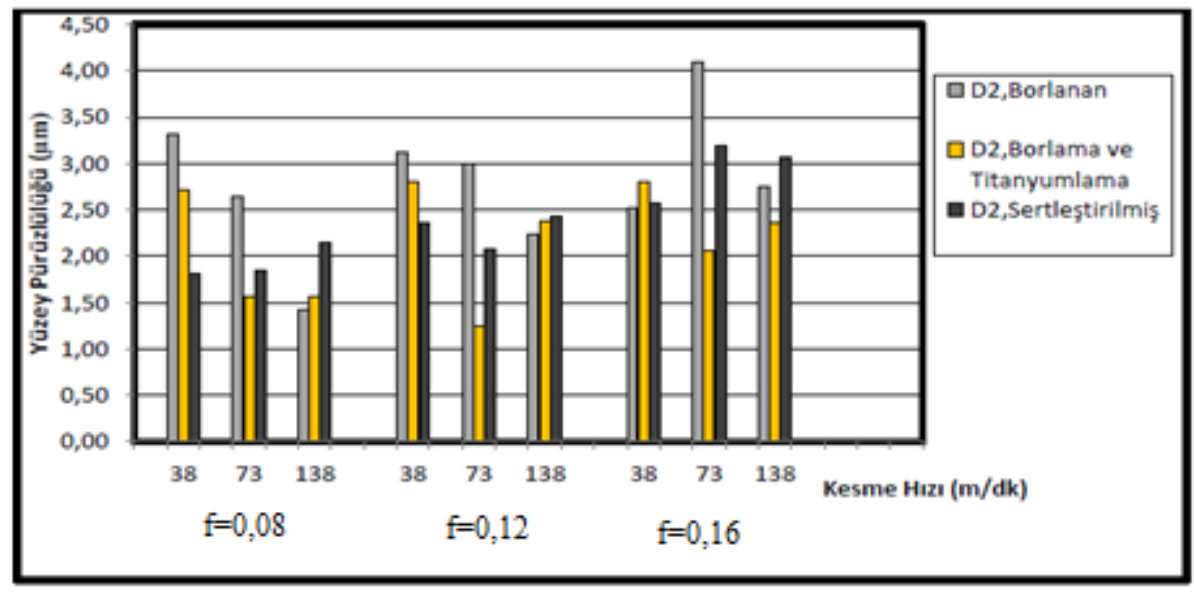

Şekil 19. Farklı AISI D2 kesici takımlarının yüzey pürüzlülüğüne etkisi

Şekil 19 incelendiğinde ilerleme hızı arttıkça yüzey pürüzlülük değerinin de genel olarak arttığ görülmüştür. Bunun, ilerleme hızındakidaki artışın yüzey üzerindeki geometrik etkisinden ve artan talaş yükünden kaynaklandığı düşünülmektedir [16]. Kesme hızındaki artış genel olarak yüzey pürüzlülügünün düşmesine neden olur. Sonuçlar nispeten bu beklentiye uygundur. Özellikle düşük ilerleme hızında bu durum daha açık bir şekilde gözlenmektedir. Bazı yüksek kesme hızı ve ilerleme şartlarında, yüzey kalitesinin düşmesi fazla miktarda takım aşınmasından kaynaklanabilir. Sonuçlar değişkenlik gösterdiğinden, takım cinsinin yüzey kalitesine etkisi hakkında belirgin veya genel bir hükme varılamamıştır.

\section{G. TAKIM AŞINMASI}

Takım aşınması sonuçları, farklı takım malzemesi ve işlem parametrelerine göre Şekil 20 de verilmiştir. Takım aşınma kriteri olarak "serbest" yüzeyde meydana gelen aşınma miktarı dikkate alınmıştır. Serbest yüzeydeki aşınma bölgesinin genişliği kesici kenara dik olarak ölçülerek elde edilen değer aşınma miktarı olarak dikkate alınmıştır. Sonuçlar incelendiğinde, kesme hızı ve ilerleme hızı arttıkça kesici takımlarda meydana gelen aşınma miktarının arttığı görülmüştür. Tüm sonuçlar dikkate alındığında 1sıl işlemle sertleştirilmiş takımla sadece borlama yapılan takım arasında aşınma direnci açısından önemli bir fark olmadığı belirlenmiştir. Bunun nedeni kaplamadaki bor tabakası kalınlığını etkileyen bor miktarı, kaplama sıcaklığı ve kaplama süresi olarak düşünülmektedir. Grafiğe bakarak, borlama ve titanyumlama işlemi yapılan takım diğerlerine kıyasla yaklaşık \%50 oranında daha az aşındığı söylenebilir. Çünkü titanyum kaplamalar yüksek sertliği ve 1sı geçirgenliğinin düşük olması nedeni ile talaşın takıma 1sı transferini engellemektedir ve takımın 1sınarak yumuşamasını önlemektedir. Sürtünme katsayısı düşük olduğundan dolayı talaş kaldırma esnasında sürtünme kuvvetleri azalmakta ve buna bağlı olarak takımın ısınması önlenerek plastik deformasyonu gecikmektedir. 


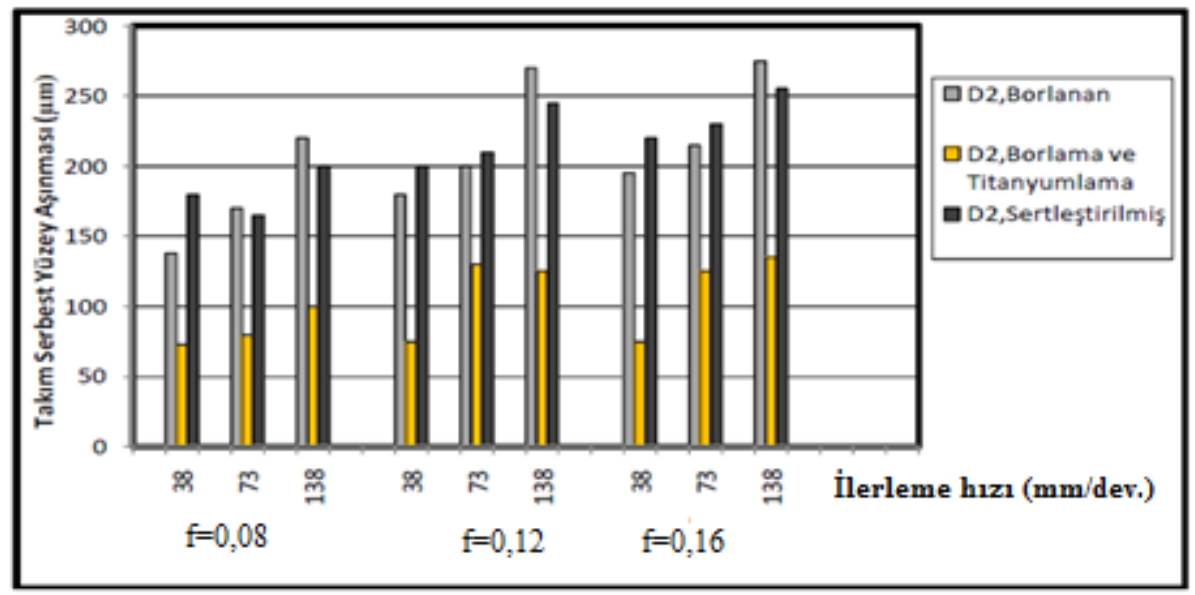

Şekil 20. Kesici takım türü ve işlem şartlarına göre oluşan takım aşınması

\section{H. TAKIM SERBEST YÜZEY AŞINMASI}

AISI D2 çeliğinden üretilen ve borlama işlemi, borlama ve titanyumlama işlemi, sertleştirme işlemi uygulanan kesici takımlarla torna tezgahında $200 \mathrm{~mm}$ boyunda otomat çeliği işlenmesi sonucunda kesici takımların talaş ve serbest yüzeylerinde meydana gelen aşınmaların fotoğrafları verilmiştir (Şekil 21, 22).

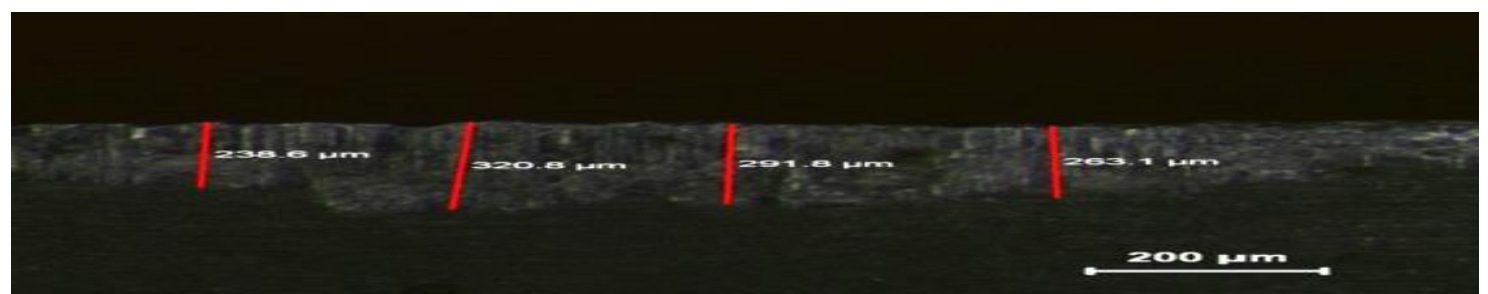

Şekil 21. Talaş kaldırma işlemi sonrasında kesici takımın serbest yüzeyinde meydana gelen aşınmalar

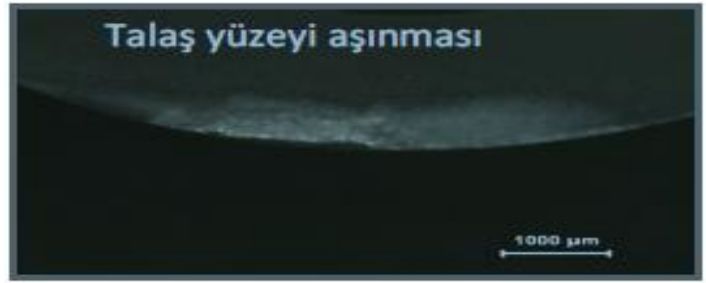

(a)

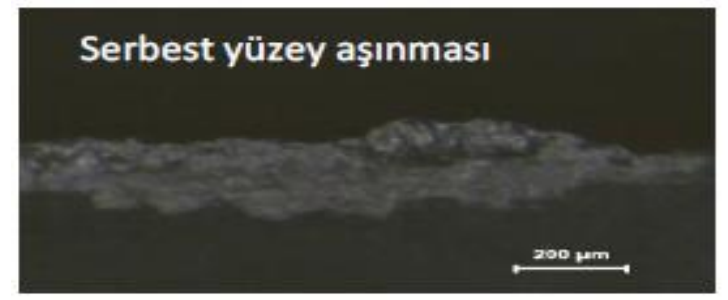

(b)

Şekil 22. $950{ }^{\circ} \mathrm{C}$ 'de 1 saat süre ile borlanan, AISI D2 kesici takım ile V=38 m/dk kesme hızında, 0,16 mm/dev. Ilerleme de otomat çeliğinden 0,25 mm talaş derinliği ile 5 pasoda kaldırılan talaş sonrasında kesici takımda meydana gelen aşınma fotoğrafları (a) talaş yüzeyi, (b) serbest yüzey 


\section{V.SONUC}

Bu çalışmada, AISI D2 çeliğinden üretilmiş kesici takım numuneler üzerinde termo-kimyasal yöntemle borlama ve borlama-titanyumlama işlemi gerçekleştirilmiştir.

- Metalografik incelemelerde borlanan AISI D2 numuneler üzerinde $\mathrm{FeB}$ ve $\mathrm{Fe}_{2} \mathrm{~B}$ fazlarından oluşan 15-25 $\mu \mathrm{m}$ kalınlığında bir tabakanın oluştuğu ve bir geçiş bölgesiyle matrise bağlandığ 1 belirlenmiştir.

- Borlama işleminden sonta titanyumlanan numuneler üzerinde yaklaşık 2-4 $\mu \mathrm{m}$ kalınlığında $\mathrm{TiB}_{2}$, TiN ve TiC bileşikelrinin oluştuğu görülmüştür.

- Borlanan yüzeylerin ortalama $2000 \mathrm{HV}$, titanyumlanan yüzeylerin ise $2800 \mathrm{HV}$ sertliğe sahip olduğu görülmüş̧ür. Bu değerler, kaplamasız sertleştirilen numuneye göre yaklaşık 3 ve 4 kat daha fazladır.

- Kesme deneyleri sonucunda borlanan ve titanyumlanan numuneler diğerlerine kıyasla yaklaşık $\% 50$ oranında daha az aşınmıştır.

- Genel olarak, işlenen yüzeyin pürüzlülüğü kesme hızıyla ters, ilerleme hızıyla doğru orantılı olarak değiştiği belirlenmiştir. Fakat bazı yüksek kesme ve ilerleme hızı şartlarında pürüzlülük değerinin yükseldiği ve bunun aşırı takım aşınmasından kaynaklandığı belirlenmiştir. Yüzey pürüzlülüğüne etkisi bakımından, tüm takımlar benzer davranış sergilemiş, takımlar arasında önemli bir fark olmadığı görülmüştür.

\section{KAYNAKLAR}

[1] S. Söderberg, M. Sjöstrand and B. Lyungberg "Advances in coating technology for metal cutting tools," Metal Powder Report, c. 56, s. 4, ss. 24-30, 2001.

[2] C. Bindal, "Az alaşımlı ve karbon çeliklerinde borlama ile yüzeye kaplanan borürlerin bazı özelliklerinin tespiti,” Doktora tezi, Fen Bilimleri Enstitüsü, İ.T.Ü, İstanbul, Türkiye, 1991.

[3] I. Ozbek and C. Bindal "Mechanical properties of boronized AISI W4 steel," Surface and cooting technology, c. 154, s. 1, ss. 14-20, 2002.

[4] K. Genel, I. Ozbek and C. Bindal "Kinetics of boriding of AISI W1 steel," Material science and engineering, c. 347, s. 1, ss. 311-314, 2003.

[5] C. K. N. Oliveira, I. C. Casteletti and A. Lombardi Neto "Production and characterization of boride layers on AISI D2 steel," Vacuum, c. 84, s. 6, ss. 792-796, 2010.

[6] K. Matiasovsky, M. Chrenkova-Paucirova, P. Fellner and M. Makyta "Electrochemical and thermochemical boriding in molten salts," Surface and coating technology, c. 35, s. 1, ss. 133-149, 1998.

[7] H. Tozan, "Termo-reaktif difüzyon yöntemiyle çelikelerin bor-titanyumlanması ve özelliklerinin incelenmesi," Yüksek lisans tezi, Fen Bilimleri Endüstrisi, Sakarya Üniversitesi, Sakarya, Türkiye, 2004.

[8] T. Arai, "Termoreactive deposition/diffusion puracess for surface," in Heat treating, 10. bask1, c. 4, Materials park, OOH: ASM International handbook, 1991, ss. 448.

[9] K. M. Gupta, K. Ramdev, S. Dharmateja and S. Sivarajan "Cutting Characteristics of PVD Coated Cutting Tools," Materials Today: Proceedings, c. 5, s. 1, ss. 11260-11267, 2018. 
[10] M. Staszuk, D. Pakuła, G. Chladek, M. Pawlyta, M. Pancielejk and P. Czaja "Investigation of the structure and properties of PVD coatings and ALD + PVD hybrid coatings deposited on sialon tool ceramics," Vacuum, c. 154, s. 8, ss. 272-284, 2018.

[11] G. Zheng, R. Xu, X. Cheng, G. Zhao, L. Li and J. Zhao "Effect of cutting parameters on wear behavior of coated tool and surface roughness in high-speed turning of 300M," Measurement, c. 125, s. 1, ss. 99-108, 2018.

[12] S. Chinchanikar and S. K. Choudhury "Wear behaviors of single-layer and multi-layer coated carbide inserts in high speed machining of hardened AISI 4340 steel," Journal of Mechanical Science and Technology, c. 27, s. 5, ss. 1451-1459, 2013.

[13] A. K. Sahoo and B. Sahoo "Experimental investigations on machinability aspects in finish hard turning of AISI 4340 steel using uncoated and multilayer coated carbide inserts," Measurement, c. 45, s. 8, ss. 2153-2165, 2012.

[14] Q. An, C. Wang, J. Xu, P. Liu and M. Chen "Experimental investigation on hard milling of high strength steel using PVD-AlTiN coated cemented carbide tool," International Journal of Refractory Metals and Hard Materials, c. 43 s. 3, ss. 94-101, 2014.

[15] W. Fichtl, N. Trausner and A. G. Matuschka, Boronizing with EKabor, ESK GmbH, 1998.

[16] Ş. Ertürk, "Termo-kimyasal yöntemle kaplanmış farklı kesici takım malzemelerinin talaşlı işlem kabiliyetinin incelenmesi," Yüksek lisans tezi, Fen Bilimleri Endüstrisi, Sakarya Üniversitesi, Sakarya, Türkiye, 2010. 